\title{
FAKTOR-FAKTOR YANG BERHUBUNGAN DENGAN KEPATUHAN BIDAN TERHADAP PENERAPAN STANDAR OPERASIONAL PROSEDUR (SOP) PELAYANAN ANTENATAL CARE
}

\author{
Septerina P.W, Pamungkas Puji R, Sumiyati \\ Poltekkes Kemenkes Semarang \\ Email: septerinapw@gmail.com
}

\begin{abstract}
In providing midwifery services, it must be in accordance with established standards, namely referring to all quality requirements of health services and equipment to meet the needs of the community. Midwife compliance with ANC service standards is influenced by several factors. This study aims to find factors related to midwives' compliance with 2019 antenatal care standard operating procedures (SOPS). The type of research used is correlational analytics. The population is all midwives who work in Jatilawang Health Center and Rawalo Health Center. The sample in this study was 44 midwives. The results showed the majority of midwives aged 21-35 years (52.3\%), educated in D3 Midwifery (93.2\%), had 11-20 years of service (47.7\%). 100\% ANC service infrastructure complete. There is no relationship between age ( $p$ value 0.323), education ( $p$ value 1.00), years of service ( $p$ value 0.471 ), and infrastructure and midwife compliance with standard operational procedures (SOP) for antenatal care services. The conclusion of this study there is no relationship between age, education, years of service, and infrastructure with midwife compliance with standard operational procedures (SOP) for antenatal care services.
\end{abstract}

Keywords: Compliance; Midwife; Antenatal Care

\section{ABSTRAK}

Dalam memberikan pelayanan kebidanan harus sesuai standar yang ditetapkan yaitu mengacu pada semua persyaratan kualitas pelayanan dan peralatan kesehatan untuk dapat memenuhi kebutuhan masyarakat. Kepatuhan bidan terhadap standar pelayanan ANC dipengaruhi oleh beberapa faktor. Penelitian ini bertujuan untuk menemukan faktor-faktor yang berhubungan dengan kepatuhan bidan terhadap standar operasional prosedur (SOP) pelayanan antenatal care tahun 2019. Jenis penelitian yang digunakan adalah analitik korelasional. Populasi yaitu seluruh bidan yang bekerja di Puskesmas Jatilawang dan Puskesmas Rawalo. Sampel dalam penelitian ini sejumlah 44 bidan. Hasil penelitian menunjukan mayoritas bidan berusia 21-35 tahun (52,3\%), berpendidikan D3 Kebidanan (93,2\%), memiliki masa kerja 11-20 tahun $(47,7 \%)$. Sarana prasarana pelayanan ANC 100\% lengkap. Tidak ada hubungan antara usia ( $p$ value 0,323 ), pendidikan ( $p$ value 1,00 ), masa kerja ( $p$ value 0,471 ), dan sarana prasarana dengan kepatuhan bidan terhadap standar operasional prosedur (SOP) pelayanan antenatal care. Kesimpulan penelitian ini tidak ada hubungan antara usia, pendidikan, masa kerja, dan sarana prasarana dengan kepatuhan bidan terhadap standar operasional prosedur (SOP) pelayanan antenatal care.

Kata Kunci: Kepatuhan; Bidan; Antenatal Care 


\section{Pendahuluan}

Angka Kematian Ibu (AKI) Di Indonesia bila dibandingkan dengan negara ASEAN lainnya masih cukup tinggi. AKI pada tahun 2015 sebesar 305/100.000 kelahiran hidup. Millenium Development Goals (MDGS) mentargetkan tahun 2015 sebesar 102 / 100.000 kelahiran hidup. Target ini dilanjutkan sebagai target Sustainable Development Goals (SDGs) yaitu 70 per 100.000 kelahiran hidup dan harus dicapai tahun 2030 (Kemenkes,2017).

World Health Organization (WHO) meluncurkan strategi MPS (Making Pregnancy Safer) tahun 1999 untuk menurunkan AKI. Salah satu intervensi strategis dalam upaya Safe Motherhood yaitu pelayanan antenatal guna pencegahan komplikasi obstetri dan adanya deteksi dini agar dapat ditangani secara memadai sehingga tidak terjadi kematian ibu (Saefudin, dkk, 2009).

Pelayanan kesehatan yang diberikan pada ibu hamil oleh tenaga kesehatan dilaksanakan sesuai dengan standar pelayanan yang ditetapkan dalam Standar Pelayanan Kebidanan/SPK disebut Antenatal care (ANC). Menurut Permenkes 97 Tahun 2014, dalam melakukan pemeriksaan antenatal, tenaga kesehatan harus memberikan pelayanan yang berkualitas sesuai standar yaitu: ukur tinggi badan, timbang berat badan, ukur tekanan darah, tentukan presentasi janin dan denyut jantung janin (DJJ), ukur lingkar lengan atas/LiLA, ukur tinggi fundus uteri, skrining status imunisasi tetanus dan memberikan imunisasi Tetanus Toksoid (TT) bila diperlukan, memberikan tablet tambah darah (tablet besi), melakukan pemeriksaan laboratorium (rutin dan khusus), melakukan tatalaksana /penanganan kasus, dan melakukan temu wicara (konseling).

AKI dapat diturunkan dengan meningkatkan standar menjaga mutu pelayanan kebidanan. Bidan adalah ujung tombak dalam upaya penurunan AKI. Sehingga pelayanan kebidanan harus bermutu dan sesuai standar sesuai persyaratan minimal pelayanan kebidanan supaya kebutuhan masyarakat terpenuhi (Purwoastuti dan Elisabeth, 2015).

Pelayanan yang bermutu adalah pelayanan sesuai dengan standar yang telah ditetapkan. Ukuran tercapainya sebuah standar dapat dilihat sesuai kepatuhan terhadap standar (Sondakh, dkk, 2013). Menurut Pohan (2003), tingkat kepatuhan merupakan ukuran kadar dari "the best practices" yang dilaksanakan oleh profesi kesehatan atau petugas Puskesmas dalam menyelenggarakan pelayanan kesehatan dasar kepada pasien. Tingkat kepatuhan dapat diukur dengan menyusun daftar tilik atau checklist standar pelayanan kesehatan.

Berdasarkan studi pendahuluan Puskesmas Jatilawang dan Puskesmas Rawalo sudah memiliki SOP pelayanan ANC dan sudah melakukan analisis kepatuhan bidan terhadap SOP pelayanan ANC dengan menggunakan daftar tilik pelayanan ANC, dimana berdasarkan studi pendahuluan kepatuhan bidan terhadap SOP pelayanan ANC dengan standar $10 \mathrm{~T}$ sudah $100 \%$ dilaksanakan. Penelitian Sholikhah (2016) menunjukan kepatuhan bidan dalam ANC berkualitas lebih mampu mendeteksi komplikasi dibandingkan bidan yang tidak menerapkan ANC sesuai standar. Bidan yang patuh mempunyai peluang $35 \%$ lebih baik melakukan deteksi komplikasi apabila dibandingkan dengan bidan yang tidak patuh.

Berdasarkan studi pendahuluan di Puskesmas Jatilawang dan Puskesmas Rawalo, diketahui bahwa prosentase ibu hamil dengan komplikasi yang ditangani pada tahun 2017 masing-masing sebesar $100 \%$ dimana terdapat 398 kasus ibu hamil dengan komplikasi di Puskemas Jatilawang dan 347 kasus di Puskesmas Rawalo. Tahun 2017 terdapat 1 (satu) kasus kematian ibu yang disebabkan karna Pre-eklampsia Berat di Puskesmas Jatilawang, sedangkan di Puskesmas Rawalo tidak ada kasus kematian ibu. Berdasarkan studi pendahuluan Puskesmas Jatilawang telah melakukan upaya pencegahan kematian ibu dengan melaksanakan pelayanan antenatal care terpadu, $\mathrm{P} 4 \mathrm{~K}$, dan pendampingan ibu hamil resiko tinggi. Ibu yang meninggal tersebut telah mendapat pelayanan antenatal dari tenaga kesehatan yang terlibat dalam antenatal care terpadu (dokter, bidan, ahli gizi, analis kesehatan, apoteker, rekam medis) dan mengikuti Program Perencanaan Persalinan dan Pencegahan Komplikasi (P4K). Bidan desa juga telah melakukan pendampingan ibu hamil resiko tinggi dengan melakukan kunjungan rumah 2 kali dalam 1 minggu. Berdasarkan studi pendahuluan adanya kematian ibu disebabkan oleh kurangnya kesadaran dan peran serta ibu hamil dan keluarga dalam mengikuti anjuran 
yang diberikan tenaga kesehatan terkait dengan masalah yang dihadapi. Hal tersebut menunjukan kurang optimalnya edukasi kesehatan kepada ibu hamil untuk meningkatkan pengetahuan, sikap dan perilaku hidup sehat pada ibu hamil.

Kepatuhan bidan dipengaruhi oleh beberapa faktor. Lawrence Green dalam Notoadmodjo, 2012 menyatakan perilaku bidan patuh terhadap SOP pelayanan ANC ditentukan oleh 3 faktor yaitu faktor pendukung (predisposing factor) meliputi pengetahuan, sikap, keyakinan, kepercayaan, nilai-nilai dan lain-lain, faktor pendorong (reinforcing factor) meliputi sikap dan perilaku petugas kesehatan yang merupakan kelompok referensi dari perilaku bidan, dan faktor pendukung (enabling factor) meliputi lingkungan fisik, tersedia atau tidaknya fasilitas-fasilitas atau sarana prasarana kesehatan. Menurut penelitian Wahyuningsih, dkk (2018), faktor yang berkaitan erat dengan kepatuhan bidan terhadap standar pelayanan antenatal yaitu pengetahuan, sikap, motivasi, usia dan masa kerja. Sedangkan menurut penelitian Nurhayani (2018), faktor yang mempengaruhi kepatuhan bidan dalam melaksanakan standar antenatal care yaitu pendidikan, sikap, motivasi, supervisi, sarana dan prasarana.

Puskesmas Jatilawang dan Puskesmas Rawalo belum melakukan analisis faktor yang berpengaruh terhadap kepatuhan bidan terhadap Standar Operasional Prosedur (SOP) pelayanan antenatal care (ANC). berlandaskan latar belakang tersebut maka penulis tergerak guna melaksanakan penelitian tentang faktorfaktor yang berhubungan dengan kepatuhan bidan terhadap standar operasional prosedur (SOP) pelayanan antenatal care tahun 2019

\section{Metode Penelitian}

Rancangan penelitian yaitu crosssectional. Adapun yang menjadi variabel dalam penelitian ini adalah umur, pendidikan, masa kerja, dan sarana prasarana sebagai variabel bebas. Kepatuhan bidan terhadap penerapan standar operasional (SOP) pelayanan antenatal care sebagai variabel terikat.

Populasi penelitian ini bidan yang bekerja di Puskesmas Rawalo dan Puskesmas Jatilawang sebanyak 44 orang. Menggunakan total sampling.
Pengumpulan data mengguanakn checklist dan kuesioner. Pada prosesnya, pengumpulan data dibantu oleh 2 enumerator yang memiliki pendidikan D III Kebidanan. Sebelumnya pelaksanaan penelitian, peneliti memberikan penjelasan terkait penelitian, intrument penelitian dan teknik pengumpulan data. Penelitian dilaksanakan di Puskesmas Rawalo dan Puskesmas Jatilawang pada bulan April 2019.

Analisis data yang digunakan meliputi analisis univariat dan analisis bivariat (Chi square atau Fischer exact)

\section{HASIL DAN PEMBAHASAN}

1. Faktor Predisposisi Kepatuhan Bidan terhadap SOP Pelayanan ANC

Tabel 1 Usia Bidan

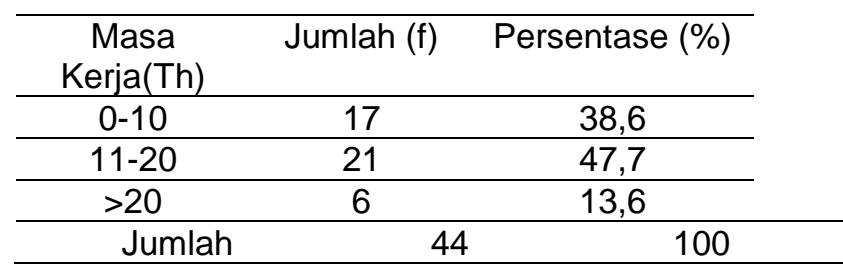

Hasil penelitian menunjukkan bahwa sebagian besar (52,3\%) Bidan berusia 21 - 35 tahun. Hal ini menjelaskan usia Bidan termasuk dalam usia dewasa dini. Menurut Damanik (2012), batas jangkauan usia dewasa awal dilihat berdasarkan aspek tugas tahap perkembangannya, yaitu memiliki pola kooperatif, kompetitif dan pola persahabatan. Tahapan usia tersebut apabila disangkutpautkan dengan aktivitas hand hygiene dapat dilaksanakan dengan penggunaan tahapan perkembangan petugas kesehatan tersebut.

Tabel 2 Pendidikan Bidan

\begin{tabular}{cccc}
\hline Pendidikan & Jumlah (f) & Persentase (\%) \\
\hline D1 & 0 & 0 & \\
\hline D3 & 41 & 93,2 & \\
\hline D4/S1 & 3 & 6,8 & \\
\hline Jumlah & 44 & & 100 \\
\hline Sebagian & besar & Bidan & $(93,2 \%)$
\end{tabular}

berpendidikan D3 Kebidanan. Menurut Undang-Undang No 12 Tahun 2012, pendidikan adalah usaha sadar dan terencana untuk mewujudkan suasana belajar dan proses pembelajaran agar peserta didik secara aktif mengembangkan potensi dirinya untuk memiliki 
kekuatan spiritual keagamaan, pengendalian diri, kepribadian, kecerdasan, akhlak mulia serta ketrampilan yang dimuliakan dirinya, masyarakat, bangsa dan negara. Pendidikan responden termasuk kategori pendidikan tinggi, dimana pendidikan Diploma III menitikberatkan pada $60 \%$ praktek dan $40 \%$ teori, dengan pendidikan yang tinggi diharapkan responden dapat memberikan pelayanan sesuai kemampuan responden

\section{Tabel 3. Masa Kerja Responden}

\begin{tabular}{cccc}
\hline Usia (Th) & Jumlah (f) & Persentase $(\%)$ \\
\hline $21-35$ & 23 & 52,3 & \\
\hline $36-45$ & 10 & 22,7 & \\
\hline $46-60$ & 11 & 25 & \\
\hline Jumlah & & 44 & \multicolumn{2}{c}{100} \\
\hline
\end{tabular}

Hasil penelitian menunjukkan bahwa mayoritas bidan $(47,7 \%)$ dengan masa kerja 11-20 tahun. Teori L.Green mengatakan salah satu faktor pendukung yang dapat mempengaruhi perilaku seseorang yaitu lama kerja. Lama kerja memberikan gambaran bahwa seorang bidan mempunyai pengalaman, ketrampilan, wawasan yang luas dan pengalaman yang bertambah dalam menerapkan tindakan akan dimiliki oleh Bidan yang sudah lama bekerja. (Marlina dan Yurnianti, 2019).

2. Faktor Pendukung Kepatuhan Bidan terhadap SOP Pelayanan ANC

Tabel 4 Sarana Prasarana Pelayanan ANC

\begin{tabular}{cccc}
\hline No & $\begin{array}{c}\text { Sarana Prasarana } \\
\text { Pelayanan ANC }\end{array}$ & $\begin{array}{c}\text { Jumlah } \\
(\mathrm{f})\end{array}$ & $\begin{array}{c}\text { Persentase } \\
(\%)\end{array}$ \\
\hline 1 & Lengkap & 44 & 100 \\
\hline 2 & Cukup lengkap & 0 & 0 \\
\hline 3 & Kurang lengkap & 0 & 0 \\
\hline & Jumlah & 44 & 100 \\
\hline
\end{tabular}

L. Green menyatakan sarana prasarana adalah faktor yang membentuk perilaku seorang individu senada dengan penelitian yang dilakukan Agustanti (2017) bahwa terdapat hubungan fasilitas dan pelaksanaan hand hygiene 5 moments pada bidan. Fasilitas yang baik memiliki peluang 24,0 kali lebih tinggi untuk merubah bidan menjadi patuh terhadap hand hygiene 5 moments dibandingkan fasilitas yang tidak baik.

\section{Kepatuhan Bidan terhadap SOP ANC}

Tabel 5 Kepatuhan Bidan terhadap SOP ANC

\begin{tabular}{|c|c|c|}
\hline $\begin{array}{l}\text { Kepatuhan Bidan } \\
\text { terhadap SOP ANC }\end{array}$ & $\begin{array}{c}\text { Jumlah } \\
\text { (f) }\end{array}$ & $\begin{array}{c}\text { Persentase } \\
(\%)\end{array}$ \\
\hline Patuh & 39 & 88,6 \\
\hline Cukup Patuh & 5 & 11,4 \\
\hline Kurang Patuh & 0 & 0 \\
\hline Jumlah & & 100 \\
\hline
\end{tabular}

Menurut Notoatmodjo, (2007) kepatuhan

bidan merupakan tingkah laku bidan terhadap suatu tindakan, prosedur atau peraturan yang harus dilakukan atau ditaati. Berdasarkan hasil penelitian mayoritas bidan patuh terhadap SOP pelayanan ANC (88,6\%). 11,4\% bidan cukup patuh terhadap SOP pelayanan ANC. Tindakan ANC yang tidak $100 \%$ dilakukan bidan diantaranya observasi keadaan umum $(2,3 \%$ tidak patuh), edema $(11,4 \%$ tidak patuh), dan tanda bahaya lainnya ( $9,1 \%$ tidak patuh), pemeriksaan suhu tubuh (2,3\% tidak patuh), pemeriksaan obstetric vulva/ perineum $(11,4 \%$ tidak patuh), pemeriksaan Inspekulo (11,4\% tidak patuh), pemeriksaan Sifilis $(9,1 \%$ tidak patuh), skrining TT (11,4\% tidak patuh).

Tabel 6 Hasil Uji Hubungan Usia dengan Kepatuhan Bidan terhadap SOP Pelayanan ANC

\begin{tabular}{|c|c|c|c|c|c|c|c|c|c|}
\hline \multirow{3}{*}{$\begin{array}{l}\text { Usia } \\
\text { (Th) }\end{array}$} & \multicolumn{8}{|c|}{ Distribusi Frekuensi } & \multirow{3}{*}{$\begin{array}{c}p- \\
\text { value }\end{array}$} \\
\hline & \multicolumn{2}{|c|}{$\begin{array}{c}\text { Kurang } \\
\text { Patuh }\end{array}$} & \multicolumn{2}{|c|}{$\begin{array}{l}\text { Cukup } \\
\text { Patuh }\end{array}$} & \multicolumn{2}{|c|}{ Patuh } & \multicolumn{2}{|c|}{ Total } & \\
\hline & $\mathrm{F}$ & $\%$ & $\mathrm{~F}$ & $\%$ & $\mathrm{~F}$ & $\%$ & $\mathrm{~F}$ & $\%$ & \\
\hline $21-35$ & 0 & 0 & 4 & 9,1 & 19 & 43,2 & 23 & 52,3 & \\
\hline $36-45$ & 0 & 0 & 1 & 2,3 & 9 & 20,5 & 10 & 22,7 & ),32 \\
\hline $46-60$ & 0 & 0 & 0 & 0 & 11 & 25 & 11 & 25 & \\
\hline Total & 0 & 0 & 5 & $\begin{array}{c}11, \\
4\end{array}$ & 39 & 88,6 & 44 & 100 & $05)$ \\
\hline
\end{tabular}

Hasil analisis hubungan usia dengan kepatuhan bidan terhadap SOP pelayanan ANC menggunakan uji chi square diperoleh nilai $p$ value $0,323(p>0,05)$ yang menunjukan bahwa tidak ada hubungan usia dengan kepatuhan terhadap SOP pelayanan ANC. Mayoritas bidan patuh terhadap SOP pelayanan ANC yaitu sebanyak 39 bidan (88,6\%). Dari 39 bidan $(88,6 \%)$ yang patuh, $43,2 \%$ berusia $21-35$ tahun, $20,5 \%$ berusia $36-45$ tahun, dan $25 \%$ berusia 46-60 tahun. Sedangkan 5 bidan $(11,4 \%)$ bidan cukup patuh terhadap SOP pelayanan ANC. Dari 5 bidan $(11,4 \%)$ cukup 
patuh, 9,1\% berusia 21-35 tahun dan sisanya 2,3\% berusia $36-45$ tahun.

Casnuri (2018) dalam penelitiannya ; tidak ada hubungan usia dengan kepatuhan bidan. Hal ini dimungkinkan pada usia berapapun manusia akan melangkah kearah hal positif ini berkaitan dengan motivasi yang ada pada dirinya sendiri. Penelitian ini sejalan dengan penelitian Khoiriyah (2016) yang menunjukan bahwa tidak ada hubungan antara umur perawat dengan kepatuhan SOP pemasangan kateter ( $p$-value 0,343). Menurut Khoiriyah (2016) semakin bertambah umur, responden menjadi lebih mengetahui bahwa menjalankan SOP kateter akan dapat meminimalkan risiko infeksi pada pasien maupun menghindari terpapar penyakit bagi responden. Hal tersebut sejalan dengan penelitian ini yang menunjukan semakin bertambah umur bidan patuh terhadap SOP pelayanan ANC. Hal tersebut terlihat dari 5 bidan (11,4\%) cukup patuh, 9,1\% berusia 21-35 tahun dan sisanya $2,3 \%$ berusia 36-45 tahun. Sedangkan bidan yang berusia 46-60 tahun $100 \%$ patuh terhadap SOP pelayanan ANC.

Marlina dan Yurnianti (2019, menunjukan tidak ada hubungan yang signifikan antara umur bidan dengan kemampuan bidan dalam melakukan inisiasi menyusu dini ( $p$ value 0.767). Ketidak sesuaian antara teori dan kenyataan dari hasil penelitian ini bisa saja disebabkan karena faktor lain, misalnya lingkungan tempat bekerja atau pihak rumah sakit yang kurang mendukung dan memberi motivasi kepada bidannya sehingga meskipun dari segi umur lebih mudah untuk menerima dan menerapkan konsep baru dan begitupun sebaliknya meski dari segi umur pemikirannya jauh lebih dewasa tanpa adanya dukungan dari pihak terkait maka penerapan dari ilmu itu akan kurang maksimal

Tabel 7 Hasil Uji Hubungan Pendidikan dengan Kepatuhan Bidanterhadap SOP Pelayanan ANC

\begin{tabular}{|c|c|c|c|c|c|c|c|c|c|}
\hline \multirow{3}{*}{$\begin{array}{l}\text { Pendi } \\
\text { dikan }\end{array}$} & \multicolumn{8}{|c|}{ Distribusi Frekuensi } & \multirow{3}{*}{$\begin{array}{c}p- \\
\text { valu } \\
e\end{array}$} \\
\hline & \multicolumn{2}{|c|}{$\begin{array}{c}\text { Kurang } \\
\text { Patuh }\end{array}$} & \multicolumn{2}{|c|}{$\begin{array}{l}\text { Cukup } \\
\text { Patuh }\end{array}$} & \multicolumn{2}{|c|}{ Patuh } & \multicolumn{2}{|c|}{ Total } & \\
\hline & $\mathrm{F}$ & $\%$ & $\mathrm{~F}$ & $\%$ & $\mathrm{~F}$ & $\%$ & $\mathrm{~F}$ & $\%$ & \\
\hline D1 & 0 & 0 & 0 & 0 & 0 & 0 & 0 & 0 & \\
\hline D3 & 0 & 0 & 5 & 11,4 & 36 & 81,8 & 41 & 93,2 & 1,00 \\
\hline $\mathrm{D} 4 / \mathrm{S} 1$ & 0 & 0 & 0 & 0 & 3 & 6,8 & 3 & 6,8 & $(p>0$ \\
\hline Total & 0 & 0 & 5 & 11,4 & 39 & 88,6 & 44 & 100 & 05) \\
\hline
\end{tabular}

Hasil analisis hubungan pendidikan dengan kepatuhan bidan terhadap SOP pelayanan ANC menggunakan uji fisher exact diperoleh nilai $p$-value $1,00 \quad(p>0,05)$ yang menunjukan bahwa tidak ada hubungan pendidikan dengan kepatuhan terhadap SOP pelayanan ANC. Mayoritas bidan patuh terhadap SOP pelayanan ANC yaitu sebanyak 39 bidan (88,6\%). Dari 39 bidan $(88,6 \%)$ yang patuh, 36 bidan $(81,8 \%)$ berpendidikan D3 dan 3 bidan $(6,8 \%)$ berpendidikan D4/S1. Sedangkan 5 bidan $(11,4 \%)$ bidan cukup patuh terhadap SOP pelayanan ANC. 5 bidan $(11,4 \%)$ tersebut berpendidikan D3 Kebidanan.

Penelitian tersebut juga sejalan dengan penelitian Khoiriyah (2016), dimana tidak ada hubungan antara pendidikan perawat dengan kepatuhan SOP pemasangan kateter ( $p$-value $0,601)$. Hal tersebut sejalan dengan penelitian ini yang menunjukan semakin tinggi pendidikan, bidan patuh terhadap SOP pelayanan ANC. Hal tersebut terlihat dari 5 bidan $(11,4 \%)$ cukup patuh berpendidikan D3 Kebidanan. Sedangkan bidan yang berpendidikan D4/S1100\% patuh terhadap SOP pelayanan ANC.

Penelitian Casnuri (2018) mendapatkan hasil bahwa tidak terdapat hubungan antara pendidikan dengan kepatuhan. Hal ini sejalan dengan penelitian Putri (2017) menunjukan tidak terdapat hubungan antara pendidikan di pelayanan antenatal pada responden penelitian ( $\mathrm{p}$ value $=0.370)$. Semakin tinggi ilmu seseorang maka akan meningkatkan kemampuan dalam melakukan aktivitas pekerjaannya. Tidak adanya hubungan yang bermakna antara pendidikan bidan dengan pelayanan antenatal sesuai standar, kemungkinan disebabkan oleh motivasi dari dalam diri bidan yang kurang dan kurangnya pengawasan dan komitmen dari bidan koordinator untuk memperhatikan setiap bidan dalam melaksanakan tindakan layanan antenatal kepada ibu hamil. Hal tersebut menyebabkan bidan tersebut tidak melaksanakan pelayanan antenatal sesuai dengan SOP yang telah ditentukan. Peneliti menyarankan kepada bidan pelaksana pelayanan antenatal di Puskesmas Kota Padang dilakukan oleh bidan dengan pendidikan yang lebih tinggi seperti bidan D3 atau bidan DIV, sehingga kemampuannya akan lebih baik. 
Hasil penelitian ini didukung oleh penelitian Marlina dan Yurnianti (2019) yang menyatakan tidak ada hubungan yang signifikan antara pendidikan bidan dengan kemampuan bidan dalam melakukan inisiasi menyusu dini ( $p$ value 0,486 ).

Tabel 8 Hasil Uji Hubungan Masa Kerja dengan Kepatuhan Bidan terhadap SOP Pelayanan ANC

\begin{tabular}{|c|c|c|c|c|c|c|c|c|c|}
\hline \multirow{3}{*}{$\begin{array}{c}\text { Masa } \\
\text { Kerja } \\
\text { (Th) }\end{array}$} & \multicolumn{8}{|c|}{ Distribusi Frekuensi } & \multirow{3}{*}{$\begin{array}{c}p- \\
\text { value }\end{array}$} \\
\hline & \multicolumn{2}{|c|}{$\begin{array}{l}\text { Kurang } \\
\text { Patuh }\end{array}$} & \multicolumn{2}{|c|}{$\begin{array}{l}\text { Cukup } \\
\text { Patuh }\end{array}$} & \multicolumn{2}{|c|}{ Patuh } & \multicolumn{2}{|c|}{ Total } & \\
\hline & $\mathrm{F}$ & $\%$ & $\mathrm{~F}$ & $\%$ & $F$ & $\%$ & $F$ & $\%$ & \\
\hline $0-10$ & 0 & 0 & 3 & 6,8 & 14 & $\begin{array}{c}31, \\
8\end{array}$ & 17 & $\begin{array}{c}38 \\
6\end{array}$ & \\
\hline $\begin{array}{l}11- \\
20\end{array}$ & 0 & 0 & 2 & 4,5 & 19 & $\begin{array}{c}43 \\
2\end{array}$ & 21 & $\begin{array}{l}47 \\
, 7\end{array}$ & 0,471 \\
\hline$>20$ & 0 & 0 & 0 & 0 & 6 & $\begin{array}{c}13, \\
6\end{array}$ & 6 & $\begin{array}{l}13 \\
, 6\end{array}$ & $\begin{array}{c}(p>0 \\
05)\end{array}$ \\
\hline Total & 0 & 0 & 5 & 11,4 & 39 & $\begin{array}{c}88, \\
6\end{array}$ & 44 & $\begin{array}{c}10 \\
0\end{array}$ & \\
\hline
\end{tabular}

Hasil analisis hubungan masa kerja dengan kepatuhan bidan terhadap SOP pelayanan ANC menggunakan uji chi square diperoleh nilai $p$-value $0,471 \quad(p>0,05)$ yang menunjukan bahwa tidak ada hubungan masa kerja dengan kepatuhan terhadap SOP pelayanan ANC. Mayoritas bidan patuh terhadap SOP pelayanan ANC yaitu sebanyak 39 bidan $(88,6 \%)$. Dari 39 bidan $(88,6 \%)$ yang patuh, 14 bidan $(31,8 \%)$ memiliki masa kerja 010 tahun, 19 bidan $(43,2 \%)$ memiliki masa kerja 11-20 tahun, dan sisanya 6 bidan $(13,6 \%)$ memiliki masa kerja $>20$ tahun. Sedangkan 5 bidan $(11,4 \%)$ bidan cukup patuh terhadap SOP pelayanan ANC. Dari 5 bidan $(11,4 \%)$ cukup patuh, 6,8\% memiliki masa kerja 0-10 tahun dan sisanya 4,5\% memiliki masa kerja 11-20 tahun.

Penelitian ini sejalan dengan penelitian Khoiriyah (2016) yang menunjukkan bahwa tidak ada hubungan antara masa kerja perawat dengan kepatuhan SOP pemasangan kateter ( $p$-value 0,338). Menurut Khoiriyah (2016) semakin bertambah masa kerja maka semakin banyak pengalaman dalam pemasangan kateter yang sesuai dengan SOP, dengan masa kerja tersebut juga diharapkan adanya pertukaran informasi mengenai pengetahuan tentang pemasangan kateter pada pasien yang sesuai dengan SOP rumah sakit. Hal tersebut sejalan dengan penelitian ini yang menunjukan semakin lama masa kerja, bidan patuh terhadap SOP pelayanan ANC. Hal tersebut terlihat dari 5 bidan $(11,4 \%)$ cukup patuh, $6,8 \%$ memiliki masa kerja 0-10 tahun dan sisanya 4,5 $\%$ memiliki masa kerja 11-20 tahun. Sedangkan bidan yang masa kerjanya >20 tahun 100\% patuh terhadap SOP pelayanan ANC.

Penelitian Putri (2017) menunjukan tidak terdapat hubungan antara lama bekerja di pelayanan antenatal pada responden penelitian ( $p$ value $=0.211)$. Semakin lama seseorang bekerja semakin bertambah pengalaman dalam melaksanakan tugas, sehingga kecakapan kerjanya semakin baik. Penelitian tersebut didukung penelitian Ruhayati dan Devi (2017), bahwa terdapat kaitan yang tidak berarti ( $\rho$ $0,226>0,05)$ antara lama kerja dengan kepatuhan bidan dalam menggunakan partograf di Kabupaten Bandung.

Tabel 9 Hasil Uji Hubungan Sarana Prasarana Pelayanan ANC dengan Kepatuhan Bidan terhadap SOP Pelayanan ANC

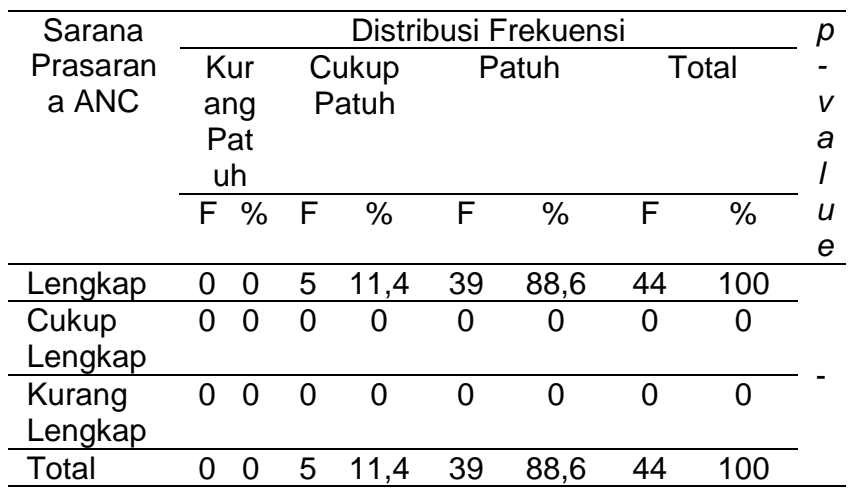

Hasil penelitian menunjukan sarana prasarana lengkap sehingga bidan patuh terhadap SOP ANC sebesar $88,6 \%$, sedangkan $11,4 \%$ bidan cukup patuh terhadap SOP ANC. Tidak ada statistik yang dihitung karena peralatan ANC adalah konstanta.

Aprilana, dkk (2016) menemukan bahwa tidak terdapat hubungan yang signifikan antara ketersediaan APD ( $p$-value 0,589) dengan perilaku penggunaan APD pada tenaga kesehatan di RSUD Banjarbaru. Hal ini tidak sejalan dengan penelitian Yuliana, dkk (2016), yang menemukan terdapat hubungan yang signifikan antara ketersediaan APD dengan penggunaan APD secara lengkap pada bidan kala II dan III. Hasil penelitian tersebut sesuai dengan teori L.Green, dimana salah satu faktor 
yang mempengaruhi perilaku seseorang yaitu sarana dan prasarana yaitu ketersediaan APD lengkap dalam kondisi yang baik. Faktor ketersediaan merupakan faktor yang memfasilitasi bidan untuk selalu menggunakan APD secara lengkap dan kondisi baik pada saat proses persalinan normal. Hal ini dikarenakan dengan ketersediaan APD secara lengkap bidan dapat menggunakan APD secara lengkap saat menolong persalinan normal. Penelitian Yuliana, dkk (2016) didukung hasil penelitian yang dilakukan Agustanti (2017), terdapat hubungan Sarana (fasilitas) dengan kepatuhan hand hygiene 5 moment pada bidan ( $p$-value $0,000 \mathrm{OR}=24,0$ ). Sarana (fasilitas) yang baik berpeluang 11,6 kali lebih tinggi untuk membuat bidan patuh terhadap hand hygiene 5 moment dibandingkan fasilitas yang tidak baik. Karena dengan fasilitas yang baik memudahkan petugas / bidan untuk selalu melakukan hand hygiene 5 moment. Jika fasilitas tidak baik ditambah motivasi yang rendah akan memicu bidan atau petugas untuk tidak patuh melakukan hand hygiene 5moment dengan alasan tidak ada fasilitas.

\section{KESIMPULAN}

Faktor predisposisi berdasarkan umur sebagian besar responden (52,3\%), berdasarkan pendidikan sebagian besar (93, 2 \%) berpendidikan D III, berdasarkan masa kerja sebagian besar $(47,7 \%)$ memiliki masa kerja 11-20 tahun. Faktor pendukung sarana prasarana pelayanan ANC $100 \%$ lengkap.

Kepatuhan bidan terhadap SOP pelayanan ANC, $88,6 \%$ bidan patuh dan $11,4 \%$ bidan cukup patuh terhadap SOP pelayanan ANC. Tidak ada hubungan antara usia ( $p$ value $0,323)$, pendidikan ( $p$ value 1,00$)$, masa kerja ( $p$ value 0,471 ), dan sarana prasarana dengan kepatuhan bidan terhadap standar operasional prosedur (SOP) pelayanan antenatal care.

\section{DAFTAR PUSTAKA}

Agustanti,N. 2017. Faktor-faktor yang mempengaruhi kepatuhan hand hygiene 5 moment pada bidan di ruang bersalin dan ruang bougenvil RSUD DR Soedirman Kebumen. Naskah Publikasi. Universitas 'Aisyiyah Yogyakarta

Anugrahini, C., Junaiti, S., Mustikasari. Kepatuhan Perawat menerapkan Pedoman
Patient Safety berdasarkan Faktor Individu dan Organisasi. Jurnal Keperawatan Indonesia, Volume 13, No. 3, November 2010, hal 139-144

Al-Assaf,A.F. 2009. Mutu Pelayanan Kesehatan: Perspektif Internasional. Jakarta. EGC

Aprillia, Yuna Trisuci. 2015. Faktor Internal Kepatuhan terhadap Pencegahan Infeksi pada Pertolongan Persalinan oleh Bidan Praktik Manidiri (BPM) di Kota " $X$ " Tahun 2013. Jurnal Bidang IImu Kesehatan Vol. 5, No. 1, Juni 2015

Apriluana,G., Laely, K., Ratna, S. 2016. Hubungan antara Usia, Jenis Kelamin, Lama Kerja, Pengetahuan, Sikap dan Ketersediaan Alat Pelindung Diri (APD) dengan Perilaku Penggunaan APD pada Tenaga Kesehatan. Jurnal Publikasi Kesehatan Masyarakat Indonesia, Vol.3 No.3, Desember 2016

Arikunto, 2010. Prosedur Penelitian Suatu Pendekatan Praktek. Jakarta. Rineka Cipta

Bastable, Susan B. 2002. Peran Perawat Sebagai Pendidik. Jakarta. Buku Kedokteran EGC.

Budiman,A., Daan, K., Hafni,B. 2013. Faktor yang Mempengaruhi Kepatuhan Berobat Pasien yang Diterapi dengan Tamoxifen Setelah Operasi Kanker Payudara. Jurnal Kesehatan Andalas. 2013;2(1)

Bungin, B. 2017. Metodologi Penelitian Kuantitatif: Komunikasi, Ekonomi, dan Kebijakan Publik Serta IImu-IImu Sosial Lainnya. Jakarta. Kencana

Casnuri. 2017. Hubungan Karakteristik dan Pengetahuan Bidan

dengan Kepatuhan Bidan terhadap Pencegahan Infeksi di BPM Wilayah Sleman Yogyakarta. Jurnal Medika Respati Vol. 13 Nomor 2 April 2018 ISSN : 1907 - 3887

Damanik,S., Sri, S., Afif, A. 2012. Kepatuhan Hand Hygiene di Rumah Sakit Immanuel Bandung. Jurnal. Universitas Padjajaran. Bandung 
Dewi, Ria Risti. 2017. Faktor Determinan Kepatuhan Perawat dalam Melakukan Praktik Cuci Tangan di RSUD Ade Muhammad Djoen Sintang. Jurnal Kesehatan Masyarakat Khatulistiwa Vol.4, No.3, Agustus2017

Efendi, F. dan Makhfudli. 2009. Keperawatan Kesehatan Komunitas: Teori dan Praktik dalam Keperawatan. Jakarta. Salemba Medika

Gulo, W. 2010. Metode Penelitian. Jakarta. Grasindo

Hidayat, A., 2011. Metode Penelitian Kebidanan dan Teknik Analisis Data. Jakarta: Salemba Medika.

Kemenkes RI. 2013. Uraian Materi Orientasi SDM dalam Pelayanan Kesehatan Maternal di Fasilitas Pelayanan Kesehatan Primer. Jakarta: Kementerian Kesehatan RI

Kemenkes RI. 2016. Mutu Layanan Kebidanan dan Kebijakan Kesehatan. Jakarta: Kementerian Kesehatan RI

2017. Profil Kesehatan Indonesia Tahun 2016. Jakarta: Kementerian Kesehatan RI

2018. Profil Kesehatan Indonesia Tahun 2017. Jakarta: Kementerian Kesehatan RI

Khoiriyah, D.A.2016. Hubungan Karakteristik Perawat terhadap Kepatuhan Menjalankan Standar Operasional Prosedur (SOP) Pemasangan Kateter di RSUD Pandan Arang Boyolali. Artikel Publikasi. STIKES Kusuma Husada. Surakarta

Marlina dan Yurniati. 2019. Faktor yang Berhubungan dengan Kemampuan Bidan dalam Melakukan Inisiasi Menyusu Dini di Wilayah Rumah Sakit Sinar Kasih Tentena Kabupaten Poso. Jurnal IImiah Forilkesuit Volume 1, Nomor 1 Februari 2019

Maternity, D., Ratna, D.P., Devy, L.N.A. 2017. Asuhan Kebidanan Komunitas -Disesuaikan dengan Rencana Pembelajaran Kebidanan. Yogyakarta: Andi

Mulatsih, T. 2017. Faktor-Faktor yang Berhubungan dengan Kepatuhan Pelaksanaan Standar Pelayanan Antenatal Care oleh Bidan Praktik Mandiri (BPM) dengan Wilayah AKI Tinggi di Kabupaten Boyolali. Naskah Publikasi. Fakultas IImu Kesehatan Universitas Muhamadiyah Surakarta.

Nurhayani. 2018. Faktor-faktor yang Mempengaruhi Kepatuhan Bidan dalam Melaksanakan Standar Antenatal Care (ANC) di Wilayah Kerja Puskesmas Pangkatan Kabupaten Labuhan Batu Tahun 2018. Tesis. Institut Kesehatan Helvetia Medan

Nurmawati. 2010. Mutu Pelayanan Kebidanan. Jakarta. TIM

Noor, J. 2017. Metodologi Penelitian Skripsi, Tesis, Disertasi, dan Karya IImiah. Jakarta: Kencana

Notoatmodjo, S. 2007. Pendidikan dan Perilaku Kesehatan. Jakarta: Rineka Cipta

.2012. Promosi Kesehatan dan Perilaku Kesehatan. Jakarta: Rineka Cipta

Pieter, H.Z, Bethsaida, J, dan Marti, S. 2011. Pengantar Psikologi untuk Keperawatan. Jakarta. Kencana

Peraturan Menteri Kesehatan Republik Indonesia Nomor 97 Tahun 2014 tentang Pelayanan Kesehatan Masa Sebelum Hamil, Masa Hamil, Persalinan, dan Masa Sesudah Melahirkan, Penyelenggaraan Pelayanan Kontrasepsi, serta Pelayanan Kesehatan Seksual.

Peraturan Menteri Kesehatan Republik Indonesia No. 28 Tahun 2017 tentang Izin dan Penyelenggaraan Praktik Bidan.

Peraturan Pemerintah No. 13 tahun 2002 tentang Pengangkatan PNS dalam Jabatan Struktural 
Pohan, I.S. 2003.Jaminan Mutu Pelayanan Kesehatan Penerapannya dalam Pelayanan Kesehatan. Jakarta: EGC.

2006. Jaminan Mutu Layanan Kesehatan: Dasar-dasar Pengertian dan Penerapan. Jakarta: EGC.

Putri,S.A. 2017. Hubungan Faktor Internal dan Eksternal Bidan dengan Pelayanan Antenatal di Puskesmas Kota Padang Tahun 2015. Tesis. Universitas Andalas

Purwoastuti, Endang dan Elisabeth Siwi Walyani. 2015. Mutu Pelayanan Kesehatan dan Kebidanan. Jakarta. Pustaka Baru Press

Puskesmas Jatilawang. 2018. Profil Puskesmas Jatilawang Tahun 2017. Jatilawang: Puskesmas Jatilawang

Puskesmas Rawalo. 2018. Profil Puskesmas Rawalo Tahun 2017. Rawalo: Puskesmas Rawalo

Robbins, S.P \& Judge, TA. 2008. Perilaku Organisasi, Edisi 12. Jakarta: Salemba Empat

Ruhayati, R. dan Devi, S. 2017. Hubungan Pengetahuan dan Lama Kerja dengan Kepatuhan Bidan dalam Menggunakan Partograf di Kabupaten Bandung. Jurnal IImiah Indonesia ISSN : 2541-0849 Vol. 2, No 4 April 2017

Saefudin, A.B., George, A., Gulardi, H., Djoko, W. 2009. Buku Acuan Nasional Pelayanan Kesehatan Maternal dan Neonatal. Jakarta: PT Bina Pustaka Sarwono Prawirohardjo.

Sholikhah,S.,Heru,P.,Mohammad,H., 2016. Kepatuhan Bidan Puskesmas dalam Penerapan Antenatal Care Terpadu Berkualitas, Deteksi Penyakit dan Komplikasi Ibu Hamil. Berita Kedokteran Masyarakat, Volume 32 No. 5 Tahun 2016

Silvia Adi Putri, 2017. Hubungan Faktor Internal dan Eksternal Bidan dengan Pelayanan Antenatal di Puskesmas Kota Padang Tahun 2015. Tesis. Universitas Andalas
Sondakh, J., Marjati, Tatarini, I.P., 2013. Mutu Pelayanan Kesehatan dan Kebidanan. Jakarta: Salemba Medika

Swarjana,I.K. 2012. Metodologi Penelitian Kesehatan. Yogyakarta. Andi

Swarjana,I.K. 2015. Metodologi Penelitian Kesehatan. Yogyakarta. Andi

Yogyakarta. Andi

2016. Statistik Kesehatan.

Syafrudin dan Hamidah. 2009. Kebidanan Komunitas. Jakarta: EGC

Tokan, R.I. 2016. Manajemen Penelitian Guru untuk Pendidikan Bermutu. Jakarta. Grasindo

Wahyuningsih, Yuwono, Andries. 2018. Faktorfaktor yang Mempengaruhi Kepatuhan Bidan terhadap Standar Pelayanan Antenatal di Kota Palembang. Jurnal. JKK, Volume 5, No 2, April 2018: 96-107 p-ISSN 2406-7431; eISSN 2614-0411

Yuliana, S.V., Ragil, I.H., Irma, P., 2016. Faktor yang Berhubungan dengan Penggunaan Alat Pelindung Diri secara Lengkap pada Bidan (Studi di Wilayah Kerja Kabupaten Bondowoso). e-Jurnal Pustaka Kesehatan, vol. 4 (no. 2) Mei 2016 